\title{
Bioconcentration of Heavy Metals in high Density traffic area of Port Harcourt Metopolis, Nigeria
}

\author{
*11WUOHA, G., ${ }^{1,2}$ OGAN, J., ${ }^{1}$ CHIKWE, T \\ ${ }^{I}$ Department of Pure and Industrial Chemistry, Faculty of Chemical Sciences, \\ College of Natural and Applied Sciences \\ University of Port Harcourt, Nigeria \\ ${ }^{2}$ Fugro Nigeria limited, Port Harcourt, Nigeria.
}

\begin{abstract}
The Bioconcentration factor $(B C F)$ of selected heavy metals in grasses growing along High Density Traffic Area (HDTA) and Low Density Traffic Area (LDTA) of Port Harcourt metropolis was ascertained. The results show BCF for Heavy Metals in grasses along HDTA are significantly higher than their counterpart along LDTA even though the values of heavy metals in the soil along the LDTA are relatively higher than those along HDTA. This shows that aerial deposition or diffusion of these Heavy Metals from automobile exhaust and adsorption processes to the grasses along HDTA plays a major role in their Bioconcentration. The order of BCF of Heavy Metals in grasses along HDTA $(\mathrm{Cr}>$ $\mathrm{Cd}=\mathrm{Co}>\mathrm{Ni}>\mathrm{Zn}>\mathrm{Pb}>\mathrm{Fe}$ ) and LDTA $(\mathrm{Cr}>\mathrm{Cd}>\mathrm{Ni}>\mathrm{Pb}>\mathrm{Co}>\mathrm{Zn}>\mathrm{Fe}$ ) shows that $\mathrm{Cr}$ and $C d$ having highest BCF of 2.97 and 2.50 in grasses along HDTA and 0.68 and 0.67 in grasses along LDTA respectively, could be used to monitor their aerial deposition from automobile exhaust. (C) JASEM
\end{abstract}

http://dx.doi.org/10.4314/jasem/v19i3.24

KEYWORDS: Heavy metal, Bioaccumulation, High Density Traffic Area, Low Density Traffic Area.

\section{Introduction}

Roadside air, vegetation and soil pollution has been observed as a result of improved road access and consequently people residing along these roads are constantly exposed to health hazard (Alloway, 1993). Environmental pollution by heavy metals from road traffics emissions has attracted so much attention globally due to long term Bioaccumulation. Heavy metal pollutants are transported to vegetation where they are transformed and bioconcentrate and thereafter are passed on to animals and human beings (Atayese et al, 2009; Suzuki et al, 2008). Oyewale et al, (2002) found that soils along kaduna-Zaria highway contain higher levels of Lead, Copper, and Zinc when compared with control soil site. Bioaccumulation, bioamplification, and bioconcentration of these heavy metals by grasses around roadsides which adsorb them heighten the fears of heavy metal toxicity.

Majority of studies on roadside concentration of heavy metals in soils, grasses and plants have been carried out in developed countries, (Otte et al; Mateu et al 1995). Nyagababo et al (1986) reported the deposition of lead, cadmium, zinc and copper from motor traffic on brachiara, einimi and soil along a major Bombo road in Kampala city. Fatoki
(1996) reported the level of Zinc and Copper concentration in roadside surface soil and vegetation-measurement of atmospheric pollution in Alice, South Africa. Abechi, et al (2010) evaluated the levels of heavy metals in roadside soils of major streets in Jos metropolis. Akoto et al (2008) reported the Heavy metal pollution in surface soils in the vicinity of abundant railway servicing workshop in Kumasi, Ghana. Al-Momani (2009), reported the assessment of trace metal distribution and contamination in surface soils of Amman, Jordan. Bai et al (2009), assessed the level of heavy metal contamination of roadside soils in Southwest China. Okunola et al (2007), reported the Levels of trace metals in soil and vegetation along major and minor roads in metropolitan city of Kaduna, Nigeria. Ndiokwere (1984), in a study reported heavy metal pollution from vehicle emission and its effect on vegetable and crops in Nigeria while Yekeen (2012) observed moderate and considerable soil pollution by heavy metals in Odo-Oba and Sabo areas respectively in Ogbomosho. However detailed reports for high density traffic areas like Port Harcourt metropolis in particular are unknown.

The aim of this paper is to ascertain the bioconcentration of heavy metals namely; Lead, Zinc, Iron, Nickel, Cobalt, Cadmium, and 
Chromium in soils and grasses around high density traffic area of Rukpokwu and low density traffic area of Rumuagholu in Port Harcourt, Rivers State.

\section{MATERIALS AND METHODS}

Study Area. Port Harcourt city is the capital of Rivers State which is located South South of Nigeria with geographical coordinates of $4^{\circ} 47^{\prime} 21^{\prime}$ 'N $6^{\circ} 59^{\prime}$ $55^{\prime \prime} \mathrm{E}$. It is a metropolitan city with population of close to two million people currently. The city host to a number of multinational oil firms, oil refineries, local and international airports.

The areas that were chosen for sampling are the major way that leads into the metropolitan city from Owerri which also links up with International airport. This route's traffic is very high all through the day but particularly during the morning and evening period. The geographical coordinates for this High Density Traffic Area (HDTA) is $4^{\circ} 89^{\prime} \mathrm{N}$ $7^{\circ} 00^{\prime} \mathrm{E}$, i.e., Rukpokwu. The other area chosen is the newly constructed dual expressway (meant to diffuse traffic from the city entrance from Owerri) that connects the city directly to the International airport. However this road was abandoned and relatively free from traffic. The geographical coordinates of the Low Density Traffic Area (LDTA) is $4^{\circ} 88^{\prime} \mathrm{N} 6^{\circ} 96^{\prime} \mathrm{E}$, i.e. Rumuagholu area. Sampling.

The sampling was done at different areas (Rukpokwu and Rumuagholu) in Port Harcourt metropolis. Areas with very high traffic volume with at least one hundred and twenty moving vehicles per minute i.e. along Port Harcourt Internationational airport highway, Rukpokwu. Areas with low traffic volume with four to five moving vehicles per minute were sampled, i.e. the new but abandoned Port Harcourt airport road, Rumuagholu. At each site three replicate samples were collected at sub-soil level to form a composite sample. On the spot $\mathrm{pH}$ values of the soil were done. The soil samples and grasses collected at the vicinity were preserved separately in polythene bags that were pre-washed with de-ionized water and thereafter taken to Fugro laboratory for analysis.

The heavy metal analysis was carried out using GBC Avanta, version 2.02 Atomic Absorption Spectrophotometer (AAS), with Acetylene/Air flame, after the samples were prepared by acid digestion. The digests were filtered through a membrane filter and aliquots of the filtrate were used to analyse for the various heavy metals.

The heavy metals were determined in accordance with APHA 3111B procedure. This method involves direct aspiration of sample into an air/acetylene flame (FAAS) and absorption of radiation generated by a hollow cathode lamp at a specific wavelength peculiar only to the heavy metal under investigation.

\section{RESULTS AND DISCUSSIONS}

The data in table 1, indicates mean the levels of the heavy metals, in soil along the roadsides of HDTA and LDTA while table 2, indicate their corresponding mean levels in grasses in the vicinity of such area. The $\mathrm{pHs}$ of the soils are 6.6 and 6.85 for HDTA and LDTA respectively.

The decreasing order of heavy metals level in $\mathrm{mg} / \mathrm{kg}$ in the soil of LDTA tallies with that of in grasses in $\mathrm{mg} / \mathrm{kg}$ along the LDTA i.e., Fe $>\mathrm{Zn}>$ $\mathrm{Cr}>\mathrm{Pb}>\mathrm{Ni}>\mathrm{Co}>\mathrm{Cd}$ with values $(\mathrm{mg} / \mathrm{kg})$ of $369>79.6>0.82>0.57>0.2>0.19>0.03$ and $9.54>2.85>0.58>0.18>0.06>0.02>0.02$ respectively. The order differs slightly for soil and grasses in HDTA. For the grasses in HDTA, the order is as follows $\mathrm{Fe}>\mathrm{Zn}>\mathrm{Cr}>\mathrm{Pb}>\mathrm{Co}>\mathrm{Ni}>$ $\mathrm{Cd}$ while the order in soil in HDTA is as follows $\mathrm{Fe}>\mathrm{Zn}>\mathrm{Pb}>\mathrm{Cr}>\mathrm{Co}>\mathrm{Ni}>\mathrm{Cd}$.

Table 1. Mean levels of some heavy metals $(\mathrm{mg} / \mathrm{kg})$ in soils along selected

\begin{tabular}{ccc} 
HDTA and LDTA of Port Harcourt metropolis \\
\cline { 2 - 3 } $\begin{array}{c}\text { PARAMETER } \\
(\mathrm{mg} / \mathrm{kg})\end{array}$ & HDTA & LDTA \\
$\mathrm{Pb}$ & 1.30 & 0.57 \\
$\mathrm{Zn}$ & 26.5 & 79.6 \\
$\mathrm{Fe}$ & 302 & 369 \\
$\mathrm{Ni}$ & 0.07 & 0.20 \\
$\mathrm{Co}$ & 0.08 & 0.19 \\
$\mathrm{Cd}$ & 0.02 & 0.03 \\
$\mathrm{Cr}$ & 0.38 & 0.82 \\
\hline
\end{tabular}

The ranges of values of heavy metals in the soil from the LDTA to HDTA are as follows; for $\mathrm{Pb}$
(0.57 to 1.30$) \mathrm{mg} / \mathrm{kg}, \mathrm{Zn}(79.6-26.5) \mathrm{mg} / \mathrm{kg}, \mathrm{Fe}$ (369-302) mg/kg, Ni (0.20-0.07) mg/kg, Co (0.19-

$$
\text { *IIWUOHA, G., }{ }^{1,2} \text { OGAN, J., }{ }^{l} \text { CHIKWE, T }
$$


$0.08) \mathrm{mg} / \mathrm{kg}, \mathrm{Cd}(0.03-0.02) \mathrm{mg} / \mathrm{kg}$ and $\mathrm{Cr}(0.82-$ $0.38) \mathrm{mg} / \mathrm{kg}$.

The values obtained for Lead in this research is below that of Abechi (2010) values for Lead in soil, which is $1.57-12.10 \mathrm{mg} / \mathrm{kg}$ equivalent. Similarly, values obtained for Cadmium are below that of Abechi (2010) values for cadmium in soil, which is $5.15-5.79 \mathrm{mg} / \mathrm{kg}$ equivalent. The mineralogical composition of the underlying hard rock in Jos, poor leaching and poor drainage might be responsible and not due to higher traffic in Jos because Port Harcourt has much more traffic than Jos but soft underlying soil and faster leaching and drainage as a result of persistent rain.

The values obtained for zinc in this research is higher than that of Abechi (2010) values for Zinc in soil, which is $5.67-12.88 \mathrm{mg} / \mathrm{kg}$ equivalent. Similarly, values obtained for Iron are above that of Abechi (2010) values for iron in soil, which is $5.15-5.79 \mathrm{mg} / \mathrm{kg}$ equivalent.

Table 2. Mean levels of selected heavy metal $(\mathrm{mg} / \mathrm{kg})$ in grasses growing along selected HDTA and LDTA of Port Harcourt metropolis.

\begin{tabular}{ccc}
\hline PARAMETER & \multicolumn{2}{c}{ RESULT } \\
\cline { 2 - 3 }$(\mathrm{mg} / \mathrm{kg})$ & HDTA & LDTA \\
$\mathrm{Pb}$ & 0.44 & 0.18 \\
$\mathrm{Zn}$ & 13.40 & 2.85 \\
$\mathrm{Fe}$ & 25.30 & 9.54 \\
$\mathrm{Ni}$ & 0.06 & 0.06 \\
$\mathrm{Co}$ & 0.20 & 0.03 \\
$\mathrm{Cd}$ & 0.05 & 0.02 \\
$\mathrm{Cr}$ & 1.13 & 0.56 \\
\hline
\end{tabular}

A close watch at the ratio of levels of these Heavy Metals in grasses in HDTA to LDTA in figure 1 shows that all Heavy Metals value are above unity for levels in grasses in HDTA. For $\mathrm{Pb}$, it is 2.44 times higher in grasses along HDTA than in the LDTA. For $\mathrm{Zn}$, it is 4.70 times higher in grasses along HDTA than in the LDTA. For Fe, it is 2.65 times higher in grasses along HDTA than in the LDTA. For Ni, it is unity. For $\mathrm{Cd}$, it is 2.5 times higher in grasses along HDTA than in the LDTA. For Cr, it is 2.02 times higher in grasses along HDTA than in the LDTA, while Co is 6.67 times higher in grasses along HDTA than in the LDTA.

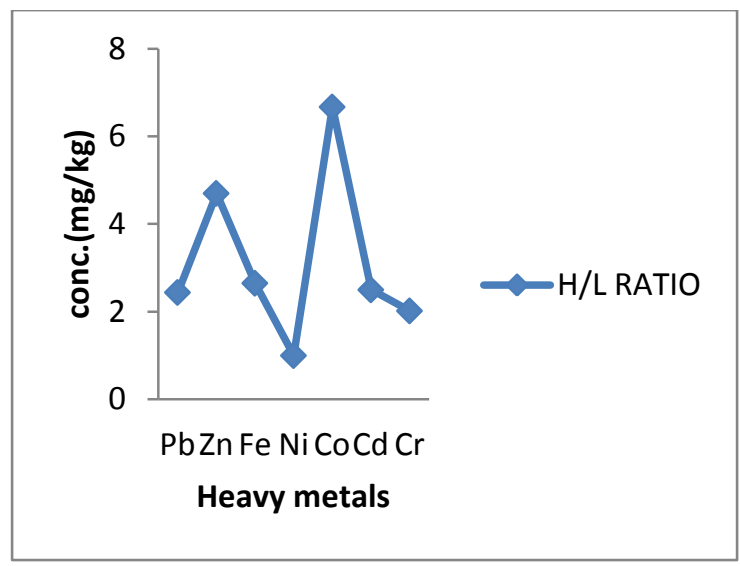

Fig 1: Values of heavy metal ratios in HDTA to LDTA in grasses

The ratio of the level of these Heavy Metals in soil along HDTA to LDTA in figure 2.0 shows that all Heavy Metal ratio except that of lead are below unity this means that lead from gaseous emission from automobile HDTA must have contributed 2.28 times to higher level in HDTA relation to LDTA. The presence of several gas filling stations along the
LDTA, poor drainage system along this areas and favorable $\mathrm{pH}$ must have contributed to higher values of other heavy metals except $\mathrm{Pb}$ on LDTA. However their respective values are relatively low and below safe limit of heavy metals in soil and it does not pose any potential hazard to the environment 


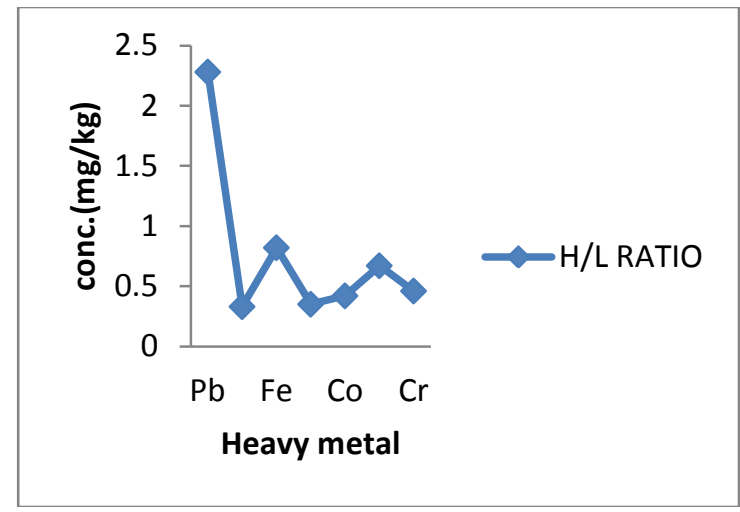

Fig: 2 Values of heavy metal ratios in HDTA to LDTA in soil

The calculation of the Bioconcentration factors (BCF) as shown in figure 3.0, of the Heavy Metals on the grass tissues shows some interesting results. For the LDTA all calculation for $\mathrm{Pb}, \mathrm{Zn}, \mathrm{Fe}, \mathrm{Ni}, \mathrm{Co}, \mathrm{Cd}$ and $\mathrm{Cr}$ are below unity, implying that we have more of the Heavy Metals in the soil than in the leaves. The result further shows that Bioamplification and Bioaccumulation of the Heavy Metals has not reached any to warrant any concern by the environmentalists. The order of the Bioconcentration factor of the Heavy Metals in the grasses along LDTA is $\mathrm{Cr}>\mathrm{Cd}>\mathrm{Ni}>$ $\mathrm{Pb}>\mathrm{Co}>\mathrm{Zn}>\mathrm{Fe}$. This vest area of bush along the LDTA is quite safe for cattle grazing. Despite higher values of Heavy Metals in the soil along the LDTA, their relative $\mathrm{BCF}$ of Heavy Metals in the grasses lower compound to their BCF levels HDTA. This show aerial diffusion in the atmosphere along the roadside of Heavy Metals from automobile fumes plays a major role in the adsorption of these Heavy Metals in the grasses.

From the table shown above, one can see the order BCF of Heavy Metals in the grasses along HDTA is $\mathrm{Cr}>\mathrm{Cd}=\mathrm{Co}>\mathrm{Ni}>\mathrm{Zn}>\mathrm{Pb}>\mathrm{Fe}$. The values $\mathrm{BCF}$ in the grasses along HDTA for $\mathrm{Cr}, \mathrm{Cd}$ and $\mathrm{Co}$ are above unity while $\mathrm{Ni}, \mathrm{Zn}, \mathrm{Pb}$, and $\mathrm{Fe}$ are below unity as indicated.

Even though the hazard potential of these grasses for animals grazing is very low, one can use them to monitor the levels of $\mathrm{Cr}$ and $\mathrm{Cd}$ in the air. In both LDTA and HDTA, Cr and Cd even though their hazard potential to the cattle grazing along these area is very low, it could be used to monitor $\mathrm{Cd}$ and $\mathrm{Cr}$ levels in the air in these areas. Biomagnification can also be monitored because these goats and cattle that graze along these areas are eventually consumed by man in the high food trophic level.

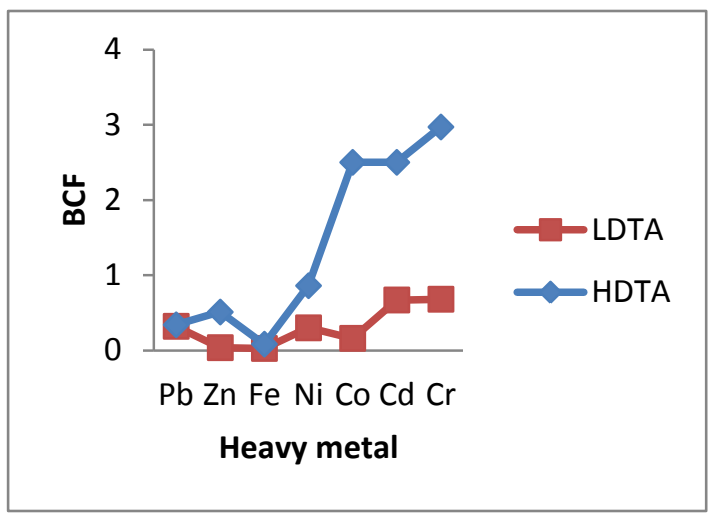

Fig 3: Bioconcentration Factor (BCF) of heavy metals along HDTA and LDTA

Conclusion: Generally, the levels of heavy metals in grasses along HDTA are significantly higher relative to their counterparts on LDTA. This is due to greater adsorption of these heavy metals that was from automobile whose number far outnumber those in LDTA. The soil along the LDTA generally contains higher heavy metals levels relative to HDTA with the exception of $\mathrm{Pb}$. This obviously shows the effect aerial release of combustion of lead petrol in exhaust of vehicles, while could have been higher if not for the good drainage along the HDTA that removes/washes away the heavy metals as soon they are settle on its top sub-soil.

The BCF of heavy metals in HDTA are significantly higher relative to LDTA even though still very below potentially toxic and hazard levels, effects most be put in place to check these factor from Bioaccumulating to hazard level or Bioamplifying.

In both HDTA and LDTA, $\mathrm{Cr}$ and $\mathrm{Cd}$ could be used to monitor their aerial deposition from automobile exhausts.

Acknowledgement: We remain grateful to the management of Fugro Nigeria Limited for allowing us make use of some of their facilities in analyzing the samples timely.

\section{REFERENCES}

Alloway, B J (1993). Heavy metals in soils. John Wiley and sons, Inc. New York. Pp. 29-39, 151196, 261-279.

Abechi, E.S: Okunola, O.J: Zubairu, S.M.J: Usman, A.A: Apene, E. (2010). Evaluation of heavy metals in roadside soils of major streets in Jos metropolis, Nigeria. Journal of Environmental Chemistry and Ecotoxicology.2(6): 98-102. 
Akoto, O: Ephraim, J.H: Darko, G. (2008).Heavy metal pollution in surface soils in the vicinity of abundant railway servicing workshop in Kumasi, Ghana. Int. J. Environ. Res.2(4): 359-364.

Al-Momani, I.F. (2009). Assessment of trace metal distribution and contamination in surface soils of Amman, Jordan.Jordan J. Chem., 4(1); 77-87.

Atayese, MO: Eigbadon, AI: Oluwa, K.A: Adesodun, J.K. (2009). Heavy metal contamination of amaranthus grown along major highways in Lagos. Afr. Crop. Sci. J.16:225-235

Bai, J., Cui, B., Wang, Q., Gao, H: Ding, Q (2009). Assessment of heavy metal contamination of roadside soils in Southwest China. Stoch. Environ. Res. Risk Ass.23 (3): 341-347.

Fatoki, O.S (1996). Trace Zinc and Copper concentration in roadside surface soil and vegetation-measurement of atmospheric pollution in Alice, South Africa. Environ int. 22: 759-762.

Mateu J:Forteza R:Cerda V:Colom-altes M (1995). Comparison of various methods for the determination of inorganic species in airborne atmospheric particulates. Water, Air, Soil Pollut., 84: 61-79.

Ndiokwere, C.L (1984). Heavy metal pollution from vehicle emission and its effect on vegetable and crops in Nigeria. Environ. Pollut., (7):35-42.
Nyagababo J.I: Hamya J.W. (1986). The deposition of Lead, Cadmium, Zinc And Copper from motor traffic on Brachiara einimi and soil along a major Bombo road in Kampala city. Int. J. Environ. Stud. 27: 115-119.

Okunola, O.J: Uzairu, A: Ndukwe, G. (2007).Levels of trace metals in soil and vegetation along major and minor roads in metropolitan city of Kaduna.Nigeria, 6, 1703-1709.

Otte M.L: Bestebroar S.J: Linden JM: Rozema J: Broekman R. A (1991). A survey of Zinc, Copper and Cadmium concentrations in salt marsh plants along the Dutch coast. Environ. Pollut., 72: 175189.

Oyewale A O: Funtua I I (2002). Lead, Copper and Zinc levels in soil along Kaduna-Zaria highway, Nigeria. Global Journal of Environmental Science, vol. 1, No 1, pp7-13.

Suzuki, K: Yabuki, T: Ono, Y. (2008). Roadside Rhododendron pulchrum leaves as bioindicators of heavy metal pollution in traffic areas of Okayama. Japan. Environ. Monit. Asses. 149:133-141

Yekeen, A T and Onifade, T O (2012). Evaluation of some Heavy metals in soils along a major a road in Ogbomosho, south west Nigeria. Journal of Environment and Earth Science. Vol. 2, No. 8: 71-79. 